\title{
GEORGE MOUSOURAKIS
}

\section{Wrongdoing, Culpability and the Logic of Criminal Law Defences}

\begin{abstract}
This article examines the question of criminal liability in terms of the theoretical distinction between justification and excuse. By contrast with German and other continental criminal law systems, the distinction has not played a significant part in the development of criminal law doctrine in common law jurisdictions. Over the past twenty years, however, there has been a growing interest in the benefits of this approach to conceptualising criminal liability, manifested by the considerable literature on justification and excuse and the frequent references to the distinction in judicial decisions and legislative enactments. Although the distinction has been given a great deal of attention in common law countries in recent years, attempts at a systematic classification of criminal law defences on this basis run up against serious difficulties. These difficulties have much to do with the fact that elements of both justification and excuse often appear to overlap in the moral basis of a legal defence. It is argued that, notwithstanding these difficulties, the theory of justification and excuse offers a viable model, which can achieve and maintain coherence among criminal law defences and facilitate understanding and acceptance of criminal law and its presuppositions.
\end{abstract}

Keywords: criminal liability, theory of justification, theory of excuse, culpability

\section{Justifications, excuses and criminal liability}

Criminal law doctrine proceeds from the principle that a person cannot be convicted of an offence unless two basic elements are established: the conduct or state of affairs which a particular offence prohibits (actus reus), and the state of mind which a person must have at the time of such conduct or state of affairs (mens rea). Establishing criminal liability depends, moreover, upon the absence of a valid legal defence. A distinction is drawn between two types of defences: justifications and excuses. A justification-based defence challenges the unlawful character of an act which, on the face of it, violates a criminal prohibition. When such a defence is raised the argument is that, in the circumstances, an act which would normally constitute a criminal offence should be considered right or, at least, legally permissible. The circumstances of justification, in other words, are understood to alter the grounds for the moral and

* Senior Lecturer in Law, University of Auckland, New Zealand.

E-mail: g.mousourakis@ auckland.ac.nz 
legal assessment of the relevant act. Self-defence and defence of another are often referred to as examples of justification-based legal defences. Claims of excuse, by contrast, do not deny the wrongfulness and unlawfulness of the act. What these defences call in question is the necessary internal relationship between a prima facie unlawful act and the actor. An accused who pleads a valid excuse cannot be held morally blameworthy and therefore culpable for having brought about the external elements of a criminal offence. Examples of this type of legal defence include insanity, duress and certain types of necessity.

Central to the theory of justification and excuse is the distinction between primary or prohibitory norms and norms of attribution. The former impose general duties of conformity with minimum standards of conduct on members of society who are required to guide their conduct accordingly if they are to avoid the sanctions provided by the law. These primary or prohibitory norms are complemented or modified by the norms of justification, which allow for exceptions to the application of the primary norms in prescribed circumstances. For example, the primary norm against committing acts of violence is complemented or modified by the provision which licenses the doing of such acts in self-defence or in defence of another. Justifications operate on the assumption that, when done under the prescribed circumstances, the act in question, harmful though it may be, should be assessed differently than when done under normal circumstances, i.e. under those in which the original prohibitory norm would apply. By contrast with the primary or prohibitory norms, the norms of attribution are specifically addressed to judges and juries as these norms lay down grounds for legally excusing someone who has violated a legal prohibition. Unlike claims of justification, the norms of attribution do not modify the primary norms. Their role is not to guide conduct but to allow for exceptions in ascribing moral blame as a prerequisite for legal culpability. According to Professor Fletcher: ${ }^{1}$

"Wrongful conduct may be defined as the violation of the prohibitory norm as modified by all defences that create a privileged exception to the norm. The analysis of attribution turns our attention to a totally distinct set of norms, which do not provide directives for action, but spell out the criteria for holding persons accountable for their deeds. The distinction as elaborated here corresponds to the more familiar distinction between justification and excuse."

\footnotetext{
${ }^{1}$ Fletcher, G.: Rethinking Criminal Law. 1978, 458.
} 
As criminal law is concerned not only with punishing wrongdoers but also with highlighting and reinforcing societal values and expectations, it should be capable of identifying the moral character of actions and the moral basis for exempting certain persons accused of offences from criminal liability and punishment. ${ }^{2}$ In this respect, describing a defence as a justification conveys the message that the relevant conduct is approved or, at least, tolerated. On the other hand, labelling a defence as an excuse draws attention to the fact that, although the actor is free from blame, his conduct remains wrongful and as such is to be avoided. A failure to recognise the distinction between justification and excuse will result in sending confusing or contradictory messages to the community. ${ }^{3}$ Besides its great moral significance, the distinction between justification and excuse has important practical implications. It is recognised, for example, that as the defence of duress operates as an excuse, a person who assists another in the commission of an offence should be convicted as an accessory even though the principal offender is excused on such grounds. By contrast, other things being equal, an alleged accessory would be free from criminal liability if the person accused of an offence as a principal successfully pleads a justification-based defence. Moreover, legally justified or authorised conduct cannot be resisted by force-e.g. one cannot justifiably use force to resist a lawful arrest, for this would undermine the greater interest being protected, i.e. the enforcement of the law-and third parties are generally entitled to assist a person whose action is deemed justified. On the other hand, because excuses do not deny the wrongful character of conduct, a person may use force to resist an attack by an excusable aggressor. ${ }^{4}$ Moreover, whether a defence is classified as a justification or as an excuse may have important consequences as regards the issue of compensation of those harmed by the accused's conduct. If the defence is regarded as an excuse a person harmed would have a strong claim for compensation. By contrast, if the defence is

2 According to M. Moore, by moral values and expectations we mean those "attitudes of resentment, moral indignation, condemnation, approval, guilt, remorse, shame, pride and the like, and that range of more cognitive judgments about when an actor deserves moral praise or blame." "Causation and Excuses" (1985), 73 California Law Review, 1091, 1144.

${ }^{3}$ See Robinson, P.: A Theory of Justification: Societal Harm as a Prerequisite for Criminal Liability. 23 University of California at Los Angeles Law Review (1975) 266, 276-277.

${ }^{4}$ See Fletcher: op. cit. 761-762; Alldridge, P.: The Coherence of Defences. [1983] Criminal Law Review, 665-666. 
classified as a justification the victim's claim for compensation would be significantly weaker. ${ }^{5}$

Commentators agree that, by contrast with German and other Continental criminal law systems, the distinction between justification and excuse has not been given enough weight in the development of modern criminal law doctrine in Common law jurisdictions. ${ }^{6}$ It is argued that much of the confusion surrounding criminal law doctrine today could have been avoided had the importance of the distinction been recognised at an earlier stage in the development of the law. ${ }^{7}$ Nevertheless, the increasing literature on justification and excuse and the frequent references to the relevant distinction in judicial decisions and legislative enactments in recent years manifest a renewed interest in the benefits of this approach to conceptualising criminal liability. ${ }^{8}$

\section{Justification and excuse in common law jurisprudence}

At early common law the distinction between justification and excuse was fully recognised and had important practical implications, particularly in the context of the law of homicide. A successful justification-based defence resulted in the full acquittal of the accused. On the other hand, an excusebased defence resulted in the usual sentence for homicide-death-and the forfeiture of the accused's property. The excused person, however, could escape execution on the grounds of a royal pardon. The Statute of Gloucester, enacted

5 See Horowitz, D.: Justification and Excuse in the Program of the Criminal Law. 1986. 49 Law and Contemporary Problems 109-122.

${ }^{6}$ See e.g., Fletcher, G.: The Individualization of Excusing Conditions. Southern California Law Review 47, (1974), 1269; The Right and the Reasonable. Harvard Law Review (1985), 949; Yeo, S. M. H.: Compulsion in the Criminal Law, 1990, 5.

7 As Professor Yeo points out: "The criminal theory concerning justification and excuse can no longer be ignored by the courts. Its primary contribution is consistency in the development of the law, a goal which the courts themselves proclaim as most desirable. Without the theory to guide the courts, aspects of the law of self-defence, duress, necessity and, until only recently provocation, have developed in an inconsistent fashion." Yeo, S. M. H.: Proportionality in Criminal Defences. Criminal Law Journal 12 (1988), 227.

8 See e.g. the decision of the Supreme Court of Canada in Perka v. R. [1984] 2 S.C.R. 232, 42 C.R. (3D) 112. As Dickson J. pointed out in that case: "Criminal theory recognizes a distinction between 'justifications' and 'excuses'. A 'justification' challenges the wrongfulness of an action which technically constitutes a crime...In contrast, an 'excuse' concedes the wrongfulness of the action but asserts that the circumstances under which it was done are such that it ought not to be attributed to the actor." ( S.C.R. 247, C.R. 128). 
in the thirteenth century, ${ }^{9}$ provided that killing another in self-preservation, like the killing of another by misadventure or accident, was excusable and therefore subject to royal pardon. The distinction between justifiable and excusable homicide was elaborated further by the commentators of the 17th and 18th centuries. In his Commentaries on the Laws of England (1769), William Blackstone distinguished between justifiable homicide as it is committed "either for the advancement of public justice or for the prevention of some atrocious crime", ${ }^{10}$ and excusable homicide which could be of two kinds: "either per infortunium, by misadventure; or se defendendo, upon a principle of self-preservation." 11 Killing in self-defence was considered excusable when two persons became engaged in a fight in the course of which deadly violence was used by one of the parties. If the killing took place in the heat of the moment, it was called "chance-medley" and the offender was guilty of the lesser crime of manslaughter. If, however, the accused had killed the other after he had retreated as far as possible, this was excusable homicide se defendendo. ${ }^{12}$

${ }^{9} 6$ Edw. I.c.9 (1278).

${ }^{10}$ Blackstone, W.: Commentaries on the Laws of England (1769), 179.

${ }^{11}$ Ibid. 82.

${ }^{12}$ Francis Bacon was one of the first English writers to comment on the distinction between justification and excuse. In discussing what he called "necessity of conservation of life" Bacon used as examples the stealing of food by a person to satisfy his present hunger and the escaping of prisoners from a jail following an accidental fire. Bacon regarded the first of these cases as an example of excusing necessity; however he treated the second case as an example of justifying necessity, a view that was to be questioned by later writers. Further, Bacon described as justifiable action one's pulling down the wall or house of another to prevent a fire from spreading and as excusable the killing of another by misfortune. Bacon, F.: The Elements of the Common Laws of England, (1630), $29 \mathrm{ff}$. And see Coke: The Third Part of the Institutes (1660), 50 ff.; Dalton, M.: Countrey Justice, (1619) $224 \mathrm{ff}$. In his Pleas of the Crown, published in 1678, Hale distinguished between three kinds of homicide: "(1) Purely voluntary, viz., murder and manslaughter; (2) purely involuntary, as that other kind of homicide per infortunium; (3) mixed, partly voluntary and partly involuntary, or in a kind necessary; and this again of two kinds, viz., including a forfeiture as se defendendo, or not including a forfeiture as (1) in defence of a man's house; (2) in defence of his person against an assault in via regia; (3) in advancement or execution of justice." (472) Hale differentiated homicides which were "justifiable, and consequently including no forfeiture at all, nor needing pardon", from homicides which were "excusable and including a forfeiture." (39-40). William Hawkins, in his Treatise of the Pleas of the Crown (1716), explained justifiable homicide as being "either of a publick or a private nature. That of a publick nature, is such as is occasioned by the due execution or advancement of publick justice. That of a private nature is such as happens in the just defence of a man's person, house, or goods." (70). Moreover, he distinguished between 
East, in his Pleas of the Crown (1803), offered a more elaborate analysis of the distinction between justifiable and excusable homicides. Three kinds of homicide ex necessitate were identified: (i) homicides in the advancement of justice, deemed justifiable by permission of the law, e.g. where a person having authority to arrest or imprison another kills the party who resists arrest in a fight; (ii) homicides in execution of justice, regarded as justifiable by the command of the law, e.g. the lawful execution of a convicted criminal; and (iii) homicides "in defence of person or property under certain circumstances of necessity" which are "either justifiable by permission of the law, or only excusable." ${ }^{\prime 13}$ In the third category East included: (i) the justifiable killing of another "who comes to commit a known felony with force against his person, his habitation, or his property" defence upon a sudden combat, described as homicide se defendendo upon chance-medley, and (iii) the killing of a person in circumstances of "dire necessity, which is not induced by the fault of either party, where one of two innocent men must die for the other's preservation: this has been held by some to be justifiable; perhaps it may more properly be considered as excusable: justification is founded upon some positive duty; excuse is due to human infirmity." " A further kind of excusable homicide, identified by East, was homicide by misadventure, which occurs "when a man doing a lawful act, without any intention of bodily harm, and using proper precaution to prevent danger, unfortunately happens to kill another person." In East's time it was recognised that in this case the "the jury under the direction of the court may

two kinds of excusable homicide: per infortunium and se defendendo. "[H]omicide per infortunium, or by misadventure...is when a man in doing a lawful act, without any intent of hurt, unfortunately chances to kill another..." (73). "[H]omicide se defendendo...seems to be where one who has no other possible means of preserving his life from one who combats with him on a sudden quarrel, or of defending his person from one who attempts to beat him...kills the person by whom he is reduced to such an inevitable necessity." (74-75). See also: Foster, M.: Crown Cases (1762), 273; Stephen, J. F.: A History of the Criminal Law of England III, (London 1883); Pollock, F. and Maitland, F.: The History of English Law. (2nd ed., 1898), 478-481; Green, T. A.: Societal Concepts of Criminal Liability in Medieval England. 1972. 47 Speculum 669, 675 ff; "The Jury and the English Law of Homicide, 1200-1600" (1976) 74 Michigan Law Review 413, 428; Kaye, J. M.: The Early History of Murder and Manslaughter. 1967. 83 Law Quarterly Review 365 and 569.

\footnotetext{
${ }^{13} 220-221$.

14221.

15221 .
} 
acquit the party, without putting him to purchase a pardon under the statute of Gloucester, c.9." 16

Although at first pardons were granted in special occasions, their number gradually increased until they came to be granted by the chancellor as a matter of course, without the need to consult the monarch. Until the pardon was confirmed, the excusable offender remained in jail or, in later years, under bail. Besides the pardon, the excused offender was granted a special writ of restitution of his goods. Gradually the practice relating to the forfeiture of the offender's goods fell into abeyance, until 1828 when forfeiture was formally abolished by statute. ${ }^{17}$ Thus, at the end, both justifications and excuses led to the same result, namely the accused's acquittal. As the difference between the effects of pleading a justification and an excuse gradually disappeared, the significance of the distinction for the common lawyer withered away and its possible role in formulating a comprehensive system of criminal law defences was subsequently overlooked. The terms justification and excuse have often been avoided by common lawyers and, when they have been used by judges and commentators, they have often been treated as interchangeable or synonymous. ${ }^{18}$ The view that came to prevail in English criminal law is that the absence of a justification or an excuse constitutes part of the legal definition of a criminal offence. According to this approach, when a person acts under a valid justification or excuse he cannot commit the offence charged. Some authors subsume the absence of such a defence under the requirement of actus reus, while others regard it as an independent definitional requirement that should be distinguished from the actus reus and mens rea elements of the offence. ${ }^{19}$ Under the latter view, a distinction should be drawn between

${ }^{16} 221-222$.

${ }^{17} 9$ Geo. IV c. 1 , s. 10 (1828).

${ }^{18}$ As one commentator remarked: "[T]he distinction between justifiable and excusable self-defence was, at one time, one of considerable importance. Moreover, it is still occasionally referred to in the cases and the two are still separately classified in the texts. However, so far as the present day law is concerned, the distinction is one without a difference... The terms are generally used synonymously and interchangeably." Miller, J.: Handbook of Criminal Law, 1934, 199. And see Stephen: History of the Criminal Law... op. cit. III, 1883, 1.

${ }^{19}$ Glanville Williams, for example, argues that: "[the] actus reus includes not merely the whole objective situation that has to be proved by the prosecution, but also the absence of any ground of justification and excuse." Criminal Law: The General Part, 1961, 20. And according to Hart, H. L. A.: "[The modern English lawyer] would simply consider both [excuse and justification] to be cases where some element, negative or positive, required in the full definition [of the offence] was lacking." Hart goes on to point out, 
excusing conditions negating the actus reus and/or mens rea elements of offences (e.g. automatism, mistake), and excusing conditions operating outside these elements (for example, duress, necessity). In the latter case the actor brings about the actus reus of an offence with the requisite intent, but criminal responsibility is precluded or diminished (in the case of a partial excuse) on the basis that, in the overwhelming circumstances the actor found himself in, his normal capacity to choose the course of his action was vitiated or substantially impaired. Sometimes the statutory definition of an offence includes the phrase "without lawful authority or excuse". It is suggested that the aim of this phrase is to serve as a reminder to judges and juries that the application of the provision creating the offence is not absolute but always subject to the absence of a recognised general defence. On the other hand, the use of the phrase "without reasonable excuse" instead of "lawful excuse" in the legal definition of an offence implies that, at the court's discretion, the accused may rely on an excuse not formally recognised by the criminal law, provided that such an excuse is reasonable. ${ }^{20}$

Professor George Fletcher has offered an important lead in re-awakening interest in the distinction between justification and excuse in Anglo-American criminal jurisprudence. Fletcher traces the decline of the distinction to the prevalence of positivistic ideas in the development of modern law. He argues that the judges' tendency to abstract the judicial decision from the individual case in order to formulate general rules of law resulted in the overlooking of the fundamental character of criminal law as "an institution of blame and punishment". ${ }^{21}$ According to Fletcher criminal condemnation and punishment presuppose a negative moral judgment of the actor's character as reflected in her voluntary violation of a criminal prohibition. From this viewpoint, excuses are seen as introducing exceptions in the application of the rules of positive law, for their role is to block the normal inference from a wrongful act that the actor's character is morally flawed. Such moral assessment of the accused's

however, that "...the distinction between these two different ways in which actions may fail to constitute a criminal offence is still of great moral importance". Hart, H. L. A.: Prolegomenon to the Principles of Punishment. In.: Punishment and Responsibility, 1968, 13.

${ }^{20}$ Smith, J. C.: Justification and Excuse in the Criminal Law: The Hamlyn Lectures, $1989,47 \mathrm{ff}$.

${ }^{21}$ Fletcher: Rethinking... op. cit. 467. See also his article "The Individualization of Excusing Conditions", Southern California Law Review 47, (1974), 1269. 
character is essential to any theory of criminal liability that connects the application of criminal punishment with the principle of just deserts. ${ }^{22}$

Fletcher argues, moreover, that the common law's reliance on the concept of reasonableness, as providing a single standard for dealing with legal disputes, tends to overshadow the distinction between justification and excuse. The common law approach is characteristic of what he calls a "flat" legal discourse-a system in which all the criteria pertinent to the resolution of a legal problem revolve around the application of a single norm. In Fletcher's words: ${ }^{23}$

"The reasonable person enables us to blur the line between justification and excuse, between wrongfulness and blameworthiness, and thus renders impossible any ordering of the dimensions of liability. The standard 'what would a reasonable person do under the circumstances?' sweeps within one inquiry questions that would otherwise be distinguished as bearing on wrongfulness or blameworthiness. Criteria of both justification and excuse are amenable to the same question."

Fletcher contrasts the common law approach with what he terms "structured" legal discourse, and points to the German law as an example. In this context legal disputes are resolved in two stages. The admission of an absolute norm, at the first stage of analysis, is followed by the introduction of qualifications introducing restrictions to the application of the norm, at the second. The distinction between justification and excuse is most at home in a system which adopts such a structured approach to defining and tackling legal disputes. In such a system, the question of wrongfulness of an act logically precedes the question of its attribution to the actor. Questions of justification, as pertinent to the issue of wrongdoing, take precedence over questions of excuse. This structured approach to criminal liability, Fletcher argues ${ }^{24}$ is consistent with a theory of criminal responsibility that lays special emphasis on retributive punishment and the principle of just deserts. From the viewpoint of retributive theory, the question of whether the actor deserves punishment cannot be considered before determining the wrongdoing to be punished. As

${ }^{22}$ Fletcher: Rethinking... op. cit. 800. See also Bayles, M.: Character, Purpose and Criminal Responsibility. Law and Philosophy 1, (1982), 5-20.

${ }^{23}$ Fletcher: The Right and the Reasonable. op. cit. 949, 962-963.

${ }^{24}$ Fletcher: Rethinking... op. cit. 961 . For an interesting account of the role of excuses from the viewpoint of retributive theories of punishment see Dressler, J.: Reflections on Excusing Wrongdoers: Moral Theory, New Excuses and the Model Penal Code. Rutgers Law Journal 19 (1988), 671. 
related to the requirement of just deserts, claims of excuse become relevant following an admission that a wrongful act has been committed.

By contrast with the general trend in modern common law jurisprudence, the distinction between justification and excuse has been instrumental in the formation of criminal law doctrine in Germany and other Continental European jurisdictions. A general account of the distinction as developed in German criminal law theory is offered in the following paragraphs.

\section{Justification and excuse in German criminal law theory}

In Germany and other Continental European legal systems legal doctrine is permeated by the fundamental idea that the normative principles of law are not reducible to the body of enacted legal rules, or law in a strict sense (Gesetz). According to Kant, the transcendental conception of law, captured in the notion of Right (Recht), pertains to the conditions of freedom that allow diverse choices in society to harmonise with each other. ${ }^{25}$ Right, or law in a broad sense, derives its binding force from its content; enacted law derives its binding force from its form-from the fact that its rules have been duly enacted by a legislative authority. The principles of the Right are perceived as preexisting and transcending the body of enacted rules whose role is merely to lay down what is to happen when the former principles are violated. An enacted rule, which by definition pertains to a specific type of legal relationship, draws on the Right, but cannot be identified with it-it is only a vinculum iuris, a bond based on Right. The application of a legal rule is typically strict, for the act or dispute is treated under the conditions specified by the letter of the law, without taking into account the circumstances of the individual case. By contrast, the application of the Right is flexible and as such adaptable to the needs of each particular case. Unlawfulness is defined primarily in relation to the Right, for an unlawful act is taken to encroach upon the normative principles which inform the particular legal provision under which the act is subsumed. ${ }^{26}$ The distinction between Right, or law in a normative sense and enacted, posited law is characteristic of continental jurisprudence. ${ }^{27}$ The

\footnotetext{
${ }^{25}$ Kant, I.: The Metaphysical Elements of Justice; and see Fletcher: The Right and the Reasonable. op. cit. 965; Fletcher: Rethinking... op. cit. $779 \mathrm{ff}$.

${ }^{26}$ See Jescheck: Lehrbuch des Strafrechts, Allgemeiner Teil (2nd ed. 1972), 154.

${ }^{27}$ Thus the Germans distinguish between Gesetz and Recht, the French between Loi and Droit, the Italians between Legge and Dirrito, the Russians between Zakon and Pravo, the Greeks between Nomos and Dikaeon.
} 
prevalence of positivistic views in Anglo-American jurisprudence precluded a similar distinction from being recognised in common law jurisdictions. The distinction between Right, or law in a broad normative sense, and enacted law, as elaborated by the jurist Karl Binding, ${ }^{28}$ allowed German theory to advance a conception of unlawfulness that goes beyond the statutory definition of a criminal offence. This development was, in turn, essential, to distinguishing between unlawfulness and guilt and, subsequently, between justification and excuse.

In German legal thinking the theory of justification and excuse emerged from the elaboration of the fundamental distinction between wrongfulness and blameworthiness. Although initially expressed in these general moral terms, this distinction was brought closer to law through a contrast between unlawfulness (Rechtswidrigkeit) and guilt (Schuld) ${ }^{29}$ The latter distinction was first recognised in the domain of private law and was subsequently introduced in criminal law theory. ${ }^{30}$ This development is associated with the emergence of the so called 'tripartite' system in German criminal law theory. Crime was described as an act which a) meets the statutory definition of an offence (Tatbestandsmassigkeit), b) is objectively unlawful (Rechtswidrig) and c) can be subjectively attributed to the actor (Schuldhaft) ${ }^{31}$ From this viewpoint, guilt was described as the subjective or internal relationship between the actor and the prescribed harm and as such it was distinguished from the objective or external unlawfulness of the act. The subjective link between the actor and the harm captured in the notion of guilt pertains to the elements of intention, recklessness and negligence. This interpretation became known as the

${ }^{28}$ Binding, K.: 1 Die Normen und ihre Übertretung 135 (1872). Binding's second important contribution to the theory of criminal liability was his analysis of guilt in terms of intention, recklessness and negligence, an approach that was widely adopted by later jurists.

${ }^{29}$ See Achenbach: Historische und dogmatische Grundlagen der strafrechtssystematischen Schuldlehre (1974) 19 ff.; Jescheck, supra note 26, $153 \mathrm{ff}$.

${ }^{30}$ As Jhering, R. first explained, the negation of the subjective blameworthiness of the actor does not necessarily preclude the wrongful act from having certain legal consequences. Das Schuldmoment im Römischen Privatrecht 4, (1867); for a fuller discussion of this matter see Eser, A.: Justification and Excuse. American Journal of Comparative Law 24 (1976), 625.

${ }^{31}$ As proposed first by Beling, E. in his Lehre vom Verbrechen (1906) and elaborated by Liszt, V. in his Lehrbuch des Deutschen Strafrechts (1919) 110 ff.; For an interesting discussion of this approach to criminal liability see Fletcher, G.: The Right Deed for the Wrong Reason: A Reply to Mr Robinson. 23 University of California at Los Angeles Law Review (1975) 293, reprinted in Michael Louis Corrado (ed), Justification and Excuse in the Criminal Law, 1994, 305. 
"psychological" theory of guilt. ${ }^{32}$ In criticising the tripartite system, some authors have argued that the satisfaction of the formal requirements of a legal provision is but another condition of unlawfulness. These authors have proposed, instead, a twofold approach to criminal liability based solely on the distinction between unlawfulness and guilt. ${ }^{33}$

The clear-cut dichotomy between objective, i.e. pertinent to unlawfulness, and subjective, i.e. pertinent to guilt, aspects of crime was finally set aside in the light of subsequent developments in German criminal theory. Jurists recognised that unlawfulness cannot be adequately canvassed without reference to certain subjective requirements. Thus, knowledge on the part of the actor that his conduct met the objective conditions of lawfulness was seen as a further condition of legal justification. Moreover, it was accepted that the notion of guilt hinges not only on subjective but also on objective considerations. The introduction of an objective element in relation to guilt meant that a claim denying attribution of an unlawful act to an accused was to be assessed also by reference to the question of what could reasonably be expected of a normal person when faced with the circumstances of pressure the accused found himself in. As a result of this development, the "psychological" theory of guilt was abandoned in favour of the so called "normative" theory of guilt. ${ }^{34}$ According to the latter theory, the requirements of guilt are not restricted to intention, recklessness and negligence, but include, in addition, considerations of capacity and control. Lack or substantial impairment of the actor's ability to comply with the law would exclude or mitigate guilt, notwithstanding his acting intentionally, recklessly or negligently. Nevertheless, the tripartite approach to criminal liability, despite the criticisms and further refinements it was subjected to, continued to be regarded as the basis of legal doctrine in German criminal jurisprudence.

James Goldschmidt was the first jurist to offer a convincing analysis of justification and excuse in German criminal jurisprudence. His theory proceeds from the fundamental distinction between legal norm (Rechtsnorm) and norm of responsibility (Pflichtnorm). ${ }^{35}$ According to Goldschmidt, a formally expressed

${ }^{32}$ Eser, A.: op. ci.t. 626-627.

${ }^{33}$ See e.g. Schmidhauser: Strafrecht, Allgemeiner Teil, (2nd ed.), 1975, 141 ff. See reference in Eser: op. cit. 627.

${ }^{34}$ As elaborated by Frank, R. in his Der Aufbau des Schuldbegriffs (1907) and Das Strafgesetzbuch fur das Deutsche Reich (18th ed. 1931) 136 ff. and Goldschmidt, J. in his "Normativer Schuldbegriff" 1 Festgabe fur R. v. Frank (1930) 428.

${ }^{35}$ Goldschmidt, J.: Der Notstand, ein Schuldproblem. 4 Osterr. Zeitschrift fur Strafrecht (1913), $144 \mathrm{ff}$. 
legal norm, i.e. a statutory provision, is tacitly complemented by a norm of responsibility requiring one to regulate her internal stance so that his actions do not conflict with the legal norm. The distinction between justification and excuse is attuned to that between legal norm and norm of responsibility. Claims of justification dispute the unlawful character of a prima facie infringement of a legal norm; claims of excuse, in contrast, challenge the violation of a norm of responsibility, i.e. the required correspondence between internal attitude and external conduct according to a legal norm. In cases of justification criminal liability is excluded by virtue of what Goldschmidt calls a "greater objective interest". In cases of excuse, on the other hand, it is excluded by virtue of an "irresistible subjective motivation". The distinction between justification and excuse, as articulated by Goldschmidt, was subjected to further theoretical elaboration and refinement and is now fully recognised in German criminal law. Thus, under the new German Penal Code, enacted in 1975, self-defence is regarded as a justification. ${ }^{36}$ The defence of necessity is treated under two separate headings: necessity as a justification, ${ }^{37}$ and necessity as an excuse. ${ }^{38}$

\section{The theory of justification and excuse as a basis for the classification of criminal law defences}

The distinction between justification and excuse offers a basic theoretical formula for understanding the way criminal law defences operate. One may seek to explain, on this basis, the demarcation of different defences as well as of different ways in which a legal defence operates or, to put it otherwise, of different pleas treated under the same label. From this viewpoint one may distinguish, for example, between self-defence as a justification and duress as

\footnotetext{
${ }^{36}$ Para 32 (Self-defence) provides: "(1) Whoever commits an act in self-defence does not act unlawfully. (2) Self-defence is that defence which is required in order to prevent a present unlawful attack on oneself or another."

${ }^{37}$ Para 34 (Necessity as justification) provides: "Whoever commits an act in order to avert an imminent and otherwise unavoidable danger to life, limb, liberty, honor, property or other legal interest of himself or of another does not act unlawfully if, taking into account all the conflicting interests, especially the legal ones, and the degree of danger involved, the interest protected by him significantly outweighs the interest which he harms. The rule applies only if the act is an appropriate means to avert the danger."

${ }^{38}$ Para 35 (Necessity as excuse) provides: "(1) Whoever commits an unlawful act in order to avert an imminent and otherwise unavoidable danger to his own life, limb, or liberty, or to that of a relative or person close to him, acts without guilt..."
} 
an excuse, as well as between justifying and excusing necessity. ${ }^{39}$ Although, at a theoretical level, the distinction between justification and excuse presents few difficulties, attempts at a general classification of the criminal law defences along these lines come up against a number of problems. These problems have much to do with the fact that, in practice, elements of excuse often appear to overlap with elements of justification. According to Greenawalt ${ }^{40}$

"The difficulty in distinguishing rests on the conceptual fuzziness of the terms 'justification' and 'excuse' in ordinary usage and on the uneasy quality of many of the moral judgments that underlie decisions that behavior should not be treated as criminal. Beyond these conceptual difficulties, there are features of the criminal process, notably the general verdict rendered by lay jurors in criminal trials, that would impede implementation in individual cases of any system that distinguishes between justification and excuse."

Greenawalt argues that there is little room for a systematic classification of criminal law defences on the basis of the justification-excuse distinction in Anglo-American law, although he does not deny the importance of the distinction in elucidating problems of moral and criminal responsibility.

Necessity offers an example of a defence whose rationale may be seen as resting upon both justificatory and excusative considerations. Necessity relates to situations where a person is forced to commit an offence in order to avoid a greater, imminent threat to himself or another. What distinguishes this defence from that of duress is that the danger which compels a person to break the law arises from the circumstances the person finds himself in, rather than from the

\footnotetext{
${ }^{39}$ As Robinson notes, it is possible to recognise "two different categories of defense under the same label at the same time and in the same jurisdiction. A jurisdiction may properly provide a 'self-defense' justification and a 'self-defense' excuse. Such multiple defenses may even occur in the same provision..." He goes on to argue, however, that "when this is done, the potential for misunderstanding and confusion increases significantly." "Criminal Law Defenses: A Systematic Analysis", 82 Columbia Law Review (1982) 199, 240. For a further discussion of this problem see Gur-Ayre, M.: Should the Criminal Law Distinguish Between Necessity as a Justification and Necessity as an Excuse? Law Quarterly Review 102 (1986), 71.

40 "The Perplexing Borders of Justification and Excuse", (1984) 84 Columbia Law Review, 1897, 1898. Consider also "Distinguishing Justifications from Excuses" (1986) 49 Law and Contemporary Problems 89. And see Eric Colvin, Principles of Criminal Law, 1991, 204-205.
} 
threats of another human being. ${ }^{41}$ Although, in Anglo-American jurisprudence, necessity is traditionally recognised as an excuse, ${ }^{42}$ questions of justification may still arise in so far as the person is still regarded as being capable of exercising a degree of choice. Thus, in English law, when an accused pleads necessity the jury are directed to consider these two interrelated questions: a) was the accused compelled to act as he did because he had a good reason to believe that otherwise he or another person would suffer death or grievous bodily harm? and $b$ ) if so, would a reasonable person, sharing the relevant characteristics of the accused, have responded to the situation the way the accused $\operatorname{did} ?^{43}$ The first of these questions is concerned with the subjective condition of compulsion, and as such it pertains to excuse; the second is concerned with the requirement of proportionality, or the objective appropriateness of the accused's conduct in the circumstances, and as such it relates to justification. The defence may be available only if, from an objective standpoint, the accused can be said to have acted reasonably and proportionately in order to avoid the forms of harm specified, i.e. death and serious bodily injury. A similar position was adopted by the Supreme Court of Canada in Perka v. $R .^{44}$ In that case it was held that necessity should be recognised as an excuse, as a concession to human frailty, and therefore it implies no vindication of the accused's actions. At the same time, however, it was stated that the defence requires a balancing of harms and that a plea of necessity should fail unless the harm inflicted was less than the harm prevented. According to this interpretation of the necessity defence, the success of the proposed compulsion-based excuse depends upon objective or justificatory considerations.

Similarly, the defence of self-defence, which is traditionally treated as a justification, may also be conceptualised as an excuse if the emphasis is placed on the assumption that a person whose life is under immediate threat is incapable of exercising free choice, i.e. acts morally involuntarily. ${ }^{45}$ This

\footnotetext{
${ }^{41}$ Hence the defence of necessity is sometimes referred to as "duress of circumstances".

${ }^{42}$ See e.g. Moore v Hussey (1609) Hob 96.

${ }^{43} R v$ Conway [1988] 3 All ER 1025; $R v$ Martin [1989] 1 All ER 652.

${ }^{44}$ Perka v R [1984] 2 S.C.R. 232; 42 C.R. (3d) 112; (1985) 14 C.C.C. (3d) 385.

${ }^{45}$ For a discussion of the rationale of self-defence see Omichinski, N.: Applying the Theories of Justifiable Homicide to Conflicts in the Doctrine of Self-Defence. 1987. 33 Wayne Law Review 1447; Fletcher, G.: The Right to Life. 1979. 13 Georgia Law Review 1371; Kadish, S.: Respect for Life and Regard for Rights in the Criminal Law. 1976. 64 California Law Review 871; Ashworth, A.: Self-Defence and the Right to Life. 1975. 34 Cambridge Law Journal 282; Dressler, J.: New Thoughts about the Concept of Justification
} 
interpretation of the defence may also be adopted in cases where force in selfdefence is used against an excusable aggressor, e.g. an insane person or a child. In such cases the aggressor's culpability in starting the fight can no longer be said to render the aggressor's rights less worthy of protection. Further, it is recognised that when the defence of self-defence is raised, a mistaken belief as to the existence or intensity of an attack and/or the psychological pressure an accused was experiencing in the circumstances (excuses) are usually taken into account in deciding whether his response was reasonable and therefore justified. ${ }^{46}$ What is known as "putative self-defence" offers another example of a defence whose rationale involves an overlap of justificatory and excusative considerations. In English law, when an accused is charged with an offence against the person and pleads self-defence or defence of another, he will be judged in the light of the circumstances as he believed them to be. The accused's belief need only be honest, not reasonable. ${ }^{47}$ What this means is that, even if the accused's actions were based on a mistaken assessment of the situation, his response will be deemed justified if the force used was reasonable in the light of that mistaken belief. It is obvious that here an excusing condition, i.e. mistake of fact, becomes an element of self-defence as a justification-based defence. One may argue, however, that in such cases the accused's initial mistake converts the entire defence into an excuse. From this viewpoint it may be said that only where the use of force, as well as the amount of force used, is objectively warranted one may speak of self-defence as a justification. ${ }^{48}$ On the other hand, it has been argued that, in moral discourse, the justification of an action is seen as depending not only on its consequences but, more importantly, on the propriety of the reasons for which the action is taken. If the emphasis is placed on this letter element, then we

in the Criminal Law: A Critique of Fletcher's Thinking and Rethinking. University of California at Los Angeles Law Review 32 (1984), 61.

${ }^{46}$ See e.g. Lord Morris' judgment in Palmer v. The Queen [1972] A.C. 814.

${ }^{47} R v$ Williams [1987] 3 All ER 411 (CA); Beckford v. R. [1988] AC 130. The traditional approach has been that for self-defence to be accepted in such cases the accused's mistake must be both honest and reasonable. This position was recognised in England prior to the decisions in Williams and Beckford and is still accepted in other common law jurisdictions. See e.g. the decision of the High Court of Australia in Zecevic v. DPP. (1987) 162 C.L.R. 645; Canadian Criminal Code, ss 27, 34, 35, 37; New Zealand Crimes Act ss 48-49.

${ }^{48}$ See e.g. Fletcher: Rethinking... op. cit. 762-769; Robinson: Criminal Law Defenses: A Systematic Analysis. supra note 39, 239-240. 
may speak of a person as acting justifiably irrespective of whether her actions, in view of their consequences, are objectively justified or not. ${ }^{49}$

Elements of justification and excuse also appear to overlap in some cases where a mitigating or partial defence is raised. A plea for mitigation may be at issue, for example, where an accused's defence of self-defence has failed on the grounds that the amount of force used was unreasonable or excessive. In such a case the accused may seek to rely on a partial excuse, claiming that under the pressure of the circumstances it was very difficult for him to assess correctly the amount of force needed to stifle the attack; or he may seek to rely on a partial justification, claiming that the fact that he was defending against an unlawful attack is sufficient to diminish the objective wrongfulness of his response. A similar overlap of excusative and justificatory elements is apparent in relation to the partial defence of provocation. Provocation, when pleaded as a partial defence to murder in English law, is not aimed at complete exoneration but only at the reduction of homicide from murder to manslaughter. Conceptually, the defence is understood to hinge upon two interrelated requirements, namely the wrongful act of provocation and impaired volition or loss of self-control. If the emphasis is placed on the assumption that the accused was acting in response to the victim's wrongdoing, the defence could be regarded as a partial justification. If, on the other hand, the emphasis is placed on the fact that the accused had lost self-control at the time of the killing, the defence would appear to operate as a partial excuse. As J. Dressler remarks $^{50}$

"Confusion surrounds the provocation defence. On the one hand, the defence is a concession to human weakness; the requirement that the defendant act in sudden heat of passion finds its roots in excuse theory. On the other hand the wrongful conduct requirement may be, and certainly some decisions based on that element are, justificatory in character. It is likely that some of the confusion surrounding the defence is inherent to the situation, but it is also probably true that English and American courts were

${ }^{49}$ See Colvin, E.: Principles of Criminal Law, 1991, 211; Dressler, J.: New Thoughts about the Concept of Justification in the Criminal Law: A Critique of Fletcher's Thinking and Rethinking", University of California Law Review, (1984), 92-95; Greenawalt, K.: The Perplexing Borders of Justification and Excuse. Columbia Law Review, (1984), 19221925.

50 "Provocation: Partial Justification or Partial Excuse?" Modern Law Review 51 (1988), 467, 480. See also Dressler: Rethinking Heat of Passion: A Defence in Search of a Rationale. 73 Journal of Criminal Law and Criminology, (1982), 421, 428. 
insufficiently concerned about the justification-excuse distinctions while the law developed."

The main obstacle to drawing a clear distinction between justifications and excuses is that, in the moral discourse, warranted conduct ranges from that which might properly be approved and encouraged through that which might only be accepted to what might be tolerated as a regrettable but unavoidable consequence of the interplay of human nature and circumstance. AngloAmerican law has attempted to circumvent these problems of moral shading by avoiding framing legal defences in terms of justification and excuse, placing the emphasis, instead, on the all-embracing requirement of reasonableness.

\section{Excuse, justification and the reasonable person}

The mythical figure of the "reasonable person" maintains a tenacious hold on Anglo-American criminal law doctrine. As Fletcher points out, law's recourse to the standard permits a continuous infusion of commonly accepted moral values into the law and, as such, constitutes an effort to go beyond the formal sources of the criminal law and to reach for "a higher, enduring, normative plane". This understanding of the "reasonable person" gains support in the light of the ever-increasing tendency towards leaving questions of reasonableness to be determined by the jury, the embodiment of community values and expectations. Nonetheless, one could not easily account for those moral considerations which underpin the "reasonable person" as the basis of a generally applicable test, nor could one prescribe the nature of the disputes to be resolved on such a basis. According to Fletcher, the law's reliance on the "reasonable person" means that heterogeneous criteria of justification and excuse, of wrongfulness and blameworthiness, are subsumed under the same inquiry and this makes it difficult to demarcate between fundamentally different perspectives of liability.

Nevertheless, the role of the "reasonable person" may be interpreted in different ways, depending on the nature of the inquiry within which the relevant standard operates. With regard to inquiries of justification, the "reasonable person" indicates the course of action that should be re-garded, in the circumstances, as legally permissible. In this respect the "reasonable person" embodies the moral principles that inform and support judgments of legal justification, recognising exceptions to the primary or prohibitory rules of the criminal law.

${ }^{51}$ Fletcher: The Right and the Reasonable. op. cit. 980. 
In this context reasonableness defines the required levels of vigilance, prudence and regard for the welfare of others which need to be met for conduct to be considered justifiable. Thus, in a situation wherein a conflict of values or interests becomes inevitable the actor is called on to act as a reasonable person, that is to preserve the value or interest which is considered as being objectively superior. From the point of view of the justification theory, such an act, harmful though it may be, should nonetheless be considered legally acceptable. Further, causing harm in pursuance of a legal right, e.g. the right of selfdefence, would not be legally warranted unless the actor observes certain limitations or, one might say, does not act "in abuse" of the right. In this regard the "reasonable person" is referred to as relevant to circumscribing the bounds within which a legal right is regarded as being properly exercised.

With regard to inquiries of excuse, on the other hand, the central question is whether the actor is fairly expected to stand up to the pressure of the circumstances and refrain from acting wrongfully. The "reasonable person" provides a yardstick in answering this question. In this context the standard of reasonableness is based on a minimalist conception of ethics. What is excluded from criminal responsibility is conduct that meets common sense expectations as to what degree of pressure ordinary people, concerned for the welfare of others, should be able to stand up to, even though such conduct may be regrettable from an idealistic viewpoint. In the context of excuse theory, the interpretation of the standard is for the most part informed by considerations having to do with what is often referred to as the "realities" or "failings" of human nature. The slide from the notion of "reasonable" to that of "ordinary" or "average" or "normal" person is sometimes suggestive of a shift from justification to excuse, as the latter notions seem more apposite to accommodate the element of human frailty. ${ }^{52}$

Although legal excuses are said to constitute concessions to the failings of human nature because it is assumed that these failings are common to all people, the combination of factors that occasion a person's surrender to pressure, as a manifestation of human frailty, could only be determined by reference to the idiosyncrasies of the particular case. Thus it becomes necessary to endow the "reasonable person" with certain individual characteristics of the accused, i.e. those that are deemed relevant to determining, in an objective way, the degree of pressure to which the actor was subjected. Only on such a basis may it properly be asked whether the accused should fairly be expected to resist the pressure and abstain from breaking the law. Of the characteristics that may bear upon the actor's capacity to withstand the compelling situation

${ }^{52}$ See Greenawalt, K.: The Perplexing Borders... op. cit. 1904-1905. 
only those for which he cannot be blamed may be taken into account in describing the ambit of the applicable test. The singling out of those individual characteristics that are material to the assessment of the proposed excuse can itself be perceived as a involving an objective moral judgment. In this respect, it seems correct to say that incorporating certain personal characteristics of the actor into the "reasonable person" standard does not in reality undermine the basically objective character of the relevant test. ${ }^{53}$ A clear distinction should be drawn, however, between individual peculiarities that may be attributed to the "reasonable person" and peculiarities whose presence would render the standard inapplicable. The latter pertain to conditions which are taken to remove the actor from the category of "reasonable" or "normal" people. As was indicated before, these conditions provide the basis for a different type of legal defence revolving around the notion of abnormality of mind rather than a general assumption of human frailty. ${ }^{54}$

\section{Concluding note}

At the heart of the theory of justification and excuse lie questions that have been the focus of moral philosophy for centuries. And the difficulties in categorising legal defences have largely to do with the confusion surrounding the choice of the moral theory upon which the role of legal defences is to be explained and justified. From the viewpoint of consequentialism, conduct is evaluated by reference to its effects. In this respect defences such as necessity and duress bear closer to justifications, for the emphasis is on whether the harm prevented by the relevant conduct outweighs the harm caused. On the other hand, the classification of the same defences as excuses reflects a nonconsequentialist, deontological approach which stresses a person's duty to abstain from performing certain actions that constitute violations of moral standards. For a deontologist, such actions remain wrongful, irrespective of their consequences, and the only way for exculpating the actor would be on the basis of an excuse. As this suggests, the same defence could be regarded as a justification or as an excuse, depending upon the moral viewpoint which one adopts.

\footnotetext{
${ }^{53}$ For a further discussion of the standard of reasonableness see Allen, H.: One Law for All Reasonable Persons? 1988. 16 International Journal of Sociology of Law 419.

${ }^{54}$ In $R$. v. Ward [1956] 1 Q.B. 351 at 356 the 'reasonable person' was described as "a person who cannot set up a plea of insanity".
} 
Notwithstanding the apparent difficulties in formulating a comprehensive system of defences on the basis of the distinction between justification and excuse, the increased emphasis on the distinction in recent years has enabled courts and legislatures to achieve a greater measure of consistency in AngloAmerican criminal law. ${ }^{55}$ The distinction has provided judges with a valuable tool in elucidating problems of criminal liability and in interpreting and declaring the law in a way that reflects more accurately community values and expectations. In the work of codification of the criminal law, legislatures rely on the distinction as a useful guide towards achieving and maintaining coherence and clarity of definition. The analysis of existing and future defence categories in terms of the theory of justification and excuse is important in bringing the criminal law closer to the community's moral values and expectations and securing a greater degree of comprehension and acceptance of the law. The theory offers a viable normative model which can achieve and maintain coherence among criminal law defences and secure community understanding and acceptance of the presuppositions upon which the criminal law system operates. This is because the very focus of the theory is on the question of rightness or wrongness of actions and society's expectations in dealing with the authors of such actions. Attention to the theory of justification and excuse will warrant the legitimacy and institutional efficacy of the criminal law system as a system which derives its aims and guiding purposes from the society which it serves.

\footnotetext{
${ }^{55}$ For a reply to the critics of the theory of justification and excuse see Dressler, J.: Justifications and Excuses: A Brief Review of the Concepts and the Literature. 1987. 33 Wayne Law Review 1155, 1168-1169. And see Yeo, S. M. H.: Compulsion in the Criminal Law, 1990, 5 ff.
} 